\section{COLD FUSION}

\section{No evidence for} \section{neutrons at Yale/BYU Washington}

IN an interim report last week to the cold fusion advisory panel of the US Department of Energy (DoE), Moshe Gai of Yale University and Steven Jones of Brigham Young University give a preliminary analysis of the results of their joint experiments, and say that there is no evidence for any anomalous emission of neutrons from titanium chips immersed in deuterium gas.

Jones has argued for a low-level solid-state fusion phenomenon (see Nature 338, 737; 1989), but Gai has done similar experiments with a negative result (see Nature 340,$29 ; 1989$ ). They agreed to collaborate on an experimentum crucis, completed about two months ago.

Their report to the DoE committee says they found no evidence for large bursts containing tens of neutrons, and a few examples of bursts containing half a dozen neutrons were "vetoed" by cosmic ray counters, indicating that the bursts were associated with external fluxes of cosmic ray particles rather than events in the experimental cells. But Jones does not regard the negative results as fatal. He says that the Yale/Brigham Young test was run for only 77 hours, which should be compared to an equivalent of 13,000 'measurement hours' now recorded by the experiment at Los Alamos National Laboratory in which he and Howard Menlove continue to see neutron bursts. The Los Alamos burst rate translates into only a 50 per cent expectation of a single burst from the Yale/Brigham Young set-up, he says, and one of the recorded bursts can be interpreted as a cosmicray event "only with some difficulty". Jones has sent a memorandum to the DoE recounting his objections. David Lindley GLOBAL WARMING

\section{North Sea changes $\mathrm{CO}_{2}$ theories}

\section{London}

ONLY 30 per cent of man-made carbon dioxide may be taken up by the oceans, rather than the $\mathbf{5 0}$ per cent predicted by existing models. This is one implication of a research programme to evaluate seasonal cycles in the North Sea, as part of the North Sea Community Project, sponsored by the UK Natural Environment Research Council (NERC). The prediction that the oceans soak up half of all man-made carbon dioxide emissions had never been rigorously tested in the field, and the discrepancy between prediction and observation has obvious implications for the study of global warming. The new results come from a study of the rate of gas exchange between the atmosphere and the surface of the sea by researchers at the Plymouth Marine Laboratory and the University of East Anglia. Henry Gee \title{
Export curbs threaten science
}

\section{Bonn}

THE circus that is West German export policy offered a new attraction last week as the conservative coalition government of Helmut Kohl rushed to redraft a hastily written law meant to restrict the transfer of weapons technology to developing countries.

There was to be an emergency meeting this week to rectify the law which, to the government's embarrassment, is supported by the opposition, but opposed by its own supporters in the coalition. The law must pass the Bundestag (the lower house of parliament) on 16 November if it is to take effect by the government's selfimposed deadline of 1 January 1990.

The law was drawn up hurriedly in response to allegations earlier this year about the participation of a West German company, Imhausen-Chemie $\mathrm{GmbH}$, in the building of a chemical weapons factory in Libya (see Nature 337, 491 and 678; 1989). The government first denied the allegations but later had to admit they were true.

Although the law is aimed principally at companies exporting equipment that could be used to produce atomic, biological or chemical weapons, it has emerged that international scientific cooperation would be one of its main victims. Cooperation would be effectively stopped by a clause requiring a government licence for the transfer of sensitive technology to countries outside the 24member OECD (Organization for Economic Cooperation and Development). Well over a hundred countries would be affected, many of which have development agreements with West Germany that necessitate technology transfer.

Scientific organizations protested against the law before a parliamentary committee here last week. "We are hopeful but not yet confident" that the law will be changed to allow cooperation as before, said Klaus Fleischmann, executive secretary of the German National Research Centres (GFE). And the general secretary of the West German Rectors' Conference (WRK), Christian Bode, wrote to the Bundestag economics committee that the new law is a "severe threat" to the success of West German research.

In February, the government introduced regulations that require a licence for technology transfer to non-OECD countries. The new law would go a step further by setting criminal penalties from 15 years to life imprisonment - for researchers or company employees found to have deliberately or negligently transferred technology to non-OECD countries.

What caused most alarm was a clause that made even the "negligent promotion" of action leading to weapons manufacture a serious crime. Harald Müller of GFE argued that, for example, if an Egyptian biologist trained in West Germany were discovered years later to be working in a biological weapons plant in Libya, his West German collaborators would be subject to arrest.

Ernst-Joachim Meusel, administrative director of the Institute for Plasma Physics (IPP) in Garching, wrote in the Frankfurter Allgemeine Zeitung that the law was drawn up with "typical German thoroughness," which in this case was "too much of a good thing".

The threat of restrictions came at an especially inopportune time for the science organizations, which just days later celebrated the " 40 th anniversary of the return of German science to the international research community". In speech after speech at a gala in Bonn on 6 October, politicians and researchers dilated on the reliance of West Germany on scientific cooperation and on West Germany's "moral obligation" to help researchers in the Soviet bloc.

WRK has suggested a clause exempting scientific cooperation from the law "as far as it is not directed toward the development or production of weapons", a modification that Fleischmann supports. Conservative parliamentarians had suggested a similar clause at the hearing.

But opposition members of the Bundestag mentioned incidents that they consider serious enough to warrant the imposition of strict penalties on individual researchers, notably the case of a physicist at the IPP in Garching accused of exporting sensitive nuclear weapons technology to Pakistan (see Nature 338, 692; 1989). Although the science organizations tend to see such incidents as isolated cases of abuse, the Social Democrats (SPD) and Greens perceive them as part of a pattern, and complain that the GFE does not take their concerns seriously enough.

Bundestag member Albrecht Müller (SPD) said that scientists "do not seem to see atomic bomb development as a serious problem", but he admitted that threatening researchers with criminal penalties is "not a happy way out".

Even if the law is amended to protect scientific exchange, the clash with the SPD has left a bitter taste in the mouths of science organizations. Intent on making things difficult for the government, the SPD has succeeded at making researchers squirm.

Steven Dickman

\section{Correction}

THE author of the News item about driftnet fishing entitled "Japan under pressure" (Nature 342, 9; 1989) is Mike Shatz. 